DOI https://doi.org/10.30525/978-9934-26-073-5-1-39

\title{
ARTISTIC CONCEPTUALIZATION IN THE COGNITIVE-DISCURSIVE PERSPECTIVE
}

\author{
Romanyshyn N. I. \\ Candidate of Philological Sciences, Associate Professor, \\ Associate Professor at the Applied Linguistics Department \\ Lviv Polytechnic National University \\ Lviv, Ukraine
}

The solution of the problem of artistic conceptualization in modern linguistics is marked by the divergence of approaches, polyphonic definitions of the artistic concept and its structure, ways of modeling the author's picture of the world and establishing its correlation with the national artistic conceptual sphere. The diversity of research perspectives is determined by the linguistic focus on the new methodological vectors, the dynamics of concepts and conceptual systems, the interaction of concepts in inter semiotic perspectives, their role in discourse $[1 ; 2 ; 3 ; 4]$. All mentioned above fosters the interdisciplinary nature of conceptual studies.

Despite the diversity and variety of modern research on artistic semantics, artistic conceptualization and a wide range of related problems, a common platform has been formed by the integration of lingual poetics, cognitive poetics, discourse and cognitive stylistics as a scientific search for revealing the correlation of linguistic structures with cognitive structures of human consciousness in the process of creation and perception of artistic text. Such integration:

- reveals the dynamics of scientific comprehension of literary text as a unique aesthetic object: from the study of verbal semantics, expressive means, text structure and compositional forms, word usage and word forms as a reflection of the author's creative potentials to the study of semantic aspects of language material, the unity of lingual and mental structures of the writer's artistic world, the nature of associative-semantic development of the text, cognitive-discursive features of information representation and knowledge structure;

- contributes to a deeper and more detailed study of the artistic concept, since in the artistic text as a space where objective and author's individual understanding of reality emerge all levels of text (especially its stylistic, linguistic and aesthetic resources that have the potential to model the world) 
are involved into the development of the conceptual information in general and into the creation of the semantic volume of a particular artistic concept;

- determines the possibility of understanding the artistic concept in cognitive-discursive and lingual poetic perspectives, that exist in unity and interaction, which highlights the duality of the nature of the artistic concept, the diversity of its structure.

Perception and interpretation of the literary text is an active process and the final stage of "author - reader" interaction system. Accordingly, the artistic text as a meaning-generating entity appears to be a connecting link of artistic and aesthetic communication, resulting in the formation of a holistic view of the author's conceptual system in the unity of its logical-conceptual, value and aesthetic manifestations. Despite its uniqueness and peculiarity, the author's artistic-conceptual model of reality correlates with the part of national experience and, following the theoretical aspects of art as a secondary modeling system, is a limited model of the "boundless world", because, according to Yu. Lotman, the model of reality created by means of art, simultaneously covers the partial and universal manifestations of the object and represents life as a whole [7, p. 205-206]. The author's individual artisticconceptual model is usually revealed as a configuration of idioconcepts, the latter being defined as mental formations with a high degree of subjectivity, modification, emphasis on certain aspects in their semantic structure that can sometimes contradict the generally accepted values [6, p. 26]. The problem of the ratio of individual-subjective and collective experience in the semantic structure of the artistic concept is solved in modern linguistics in different ways. Some scholars are convinced that the author's conceptual model is based on a reconsidered and in a special way reorganized system of cultural concepts. Others emphasize the unique heuristic potential of artistic concepts in the perception and conceptualization of reality, which is based on the cognitive essence of art $[4$, p. $60 ; 8 ; 9]$. Both in the cases when the artistic concepts are artificially constructed to express the author's intention and when artistic conceptualization is based on the artist's "experience" of concepts already present in the ethnic consciousness, their combination as a method of revealing a holistic spiritual position, author's priorities and aesthetic dominants is the result of secondary comprehension of the conceptualized phenomenon.

The author - writer / poet - as a subject of artistic cognition, aesthetic, pragmatic and creative activity programs and directs the reception of the conceptual model of the depicted phenomenon, embedded in the multilevel semiotic reality of the artistic world by appropriate textual means - imageassociative, expressive, stylistic, compositional, a palette of stipulated imagery of complex semantics, created by the interaction of denotative and connotative 
aspects of the meaning of language units. Artistic meaning-making is like a game in which no textual plan matters in its purest form. Sense is the result of the interaction of textual details that are part of different systems of relations. The ambiguity of the artistic semantics of the literary work and the versatility of interpretations of the artistic conceptual model is determined by the factor of reader's reception [5, p. 4], given by a complex of socio-cultural, aesthetic, emotional and psychological factors, the dynamics of linguistic and communicative competence of the addressee, the influence of the historical context (both on the creation and perception of the text).

The comprehension of the "two-dimensionality" (author-centrism and addressee-centrism) of the conceptual model of reality as a result of artistic and aesthetic communication in the plane of "linguistic artistic cognition culture" renews the perception of its main element - the artistic concept. The artistic concept as a manifestation of the organic interdependence of the form and content of the work can constellate the system of semantic organization of collective and author's subjective ethnic consciousness in cognitive-discursive, pragmatic, aesthetic and socio-psychological planes. Identification of artistic concepts and artistic-conceptual models on the basis of cognitive-discursive approach involves the application of the principles of hermeneutics and integration of research tools of linguistics, cultural studies and literary criticism, which builds an algorithm from the analysis of the concept as a mental structure to its embodiment - explicit and implicit - at different levels of textual matter. Simultaneous involvement of the provisions of literary criticism and linguistics in the scientific analysis makes it possible to consider artistic semantics comprehensively, to trace the impact of cultural images in the multidimensionality of artistic concepts, individual and collective experience as a reflection and transformation of reality. The integration of different philological disciplines allows to understand the connection and interdependence of cognitive (related to the formation and transfer of knowledge) and communicative (as a product and object of communicative-cognitive activity) aspects of artistic discourse with the nature of author's creative activity, type of author's consciousness, artistic ideas, methods of artistic solution to the problems raised by the author. In the cognitive-discursive perspective of understanding the essence of the artistic concept we rely on the position of dialogic nature of the artistic concept, in the semantic structure of which there are combined and interacted the cultural, historical, ideological and evaluative aspects determined by cognitive and linguo-creative activity of the author and recipient during artistic communication. The result of artistic and aesthetic communication is the formation of a holistic view of the author's conceptual system as an organic unity of logical-conceptual, axiological and aesthetic manifestations. 


\title{
References:
}

1. Алефиренко Н. Ф. Проблемы вербализации концепта: теоретическое исследование. Волгоград: Перемена, 2003. 96 с.

2. Бєлєхова Л. І. Словесний поетичний образ в історико-типологічній перспективі: лінгвокогнітивний аспект (на матеріалі американської поезії). Херсон: Айлант, 2002. 367 с.

3. Воробйова О. П. Когнітивна поетика: здобутки і перспективи. Вісник Харківського національного університету ім. В. Н. Каразіна. 2004. Вип. 635. С. 18-22.

4. Воробйова О. П. Концептологія в Україні: здобутки, проблеми, прорахунки. Вісник КНЛУ. Сер.: Філологія. 2011. Т. 14, № 2. С. 53-64.

5. Еко У. Роль читача: дослідження з семіотики текстів: пер. 3 англ. / пер. Мар'яна Гірняк. Львів: Літопис, 2004. 383 с.

6. Карасик В. И. Языковые ключи. Москва: Гнозис, 2009. 387 с.

7. Лотман Ю. Об искусстве. Структура художественного текста. Санкт-Петербург: Искусство, 1998. URL: https://www.gumer.info/ bibliotek_Buks/Literat/Lotman/_Index.php (дата обращения: 13.04.2021).

8. Миллер Л. В. Лингвокогнитивные механизмы формирования художественной картины мира (на материале русской литературы): дис. ... д-ра филол. наук. Санкт-Петербург, 2004. 303 с.

9. Миллер Л. В. Художественный концепт как смысловая и эстетическая категория. Мир русского слова. 2000. № 4. С. 39-45.

DOI https://doi.org/10.30525/978-9934-26-073-5-1-40

\section{EVALUATION AND INTERPRETATION OF TOBIAS SMOLLETT'S NOVEL 'THE EXPEDITION OF HUMPHRY CLINKER'}

\author{
Ruskykh I. V. \\ Senior Lecturer at the Social and Humanities Department \\ Dnipropetrovsk State University of Internal Affairs \\ Dnipro, Ukraine
}

A famous journalist, editor, historian, critic, and pamphleteer involved in publishing and politics, turning to novel writing as a respite, Smollett will rejoin the reader in the successful role of the author of «Humphry Clinker» (1771), a work that sums up his accomplishments as a novelist. Wide professional and personal dramatic experience will lead the writer to a very 